\title{
HOE DRYF ONS DIE DUIWELS UIT
}

\section{Enkele voorlopige opmerkings oor die betekenis van 'n}

\section{Christelike mensbeskouing vir die pastoraat}

\author{
Dr. B. J. van der Walt
}

1. Elke psigologie, psigoterapie en pastoraal is gebou op 'n bepaalde antropologie (of 'n konglomeraat van antropologië̈ a.g.v. 'n elektriese werkswyse)

Daaroor hoef ons seker nie te debatteer nie. Hiermee word nie geimpliseer dat alle psigoloë, psigoterapeute en pastors altyd duidelik bewus is van hul antropologiese uitgangspunte nie. Ek wil die stelling waag dat sulke mense nie hul werk na behore kan verrig nie. 'n Terapeut of 'n pastor wat pasiënte probeer help sonder deeglike kennis van wie en wat die mens is, is iemand wat self behandeling nodig het! As gevolg van sy selferkende blindheid kan hy meer kwaad as goed doen.

'n Eenvoudige illustrasie sal voldoende wees. Die meeste mense kies hulle dokter met sorg. Faktore soos sy bekwaamheid en sy betroubaarheid as mens is belangrike oorwegings.

Emosionele gesondheid is dalk 'n nog groter gawe as liggaamlike gesondheid, want dit bring ontspanning, kleur, warmte, intensiteit, gerigtheid en openheid in ' $n$ mens se bestaan. Daarom sal 'n mens graag iets meer wil weet van die persoon van wie jy psigiatriese behandeling gaan ontvang. Nie net wat hierdie man weet en in staat is om te doen nie maar ook wie hy is, is belangrik. Van nie minder belang is wat hy van die mens in die algemeen dink (m.a.w. sy eie mensbeskouing)) en die pasiënt in besonder. Is hy bv. bewus daarvan dat nie elke teorie oor die mens 'n Christelike teorie is nie?

Die vraag vir ons is nie of die pastoraat 'n antropologiese basis nodig het nie - dit is 'n uitgemaakte saak (of die psigoterapeut of pastor daarvan bewus is of nie) - maar slegs watter antropologie as vertrekpunt geneem word.

\section{Van watter antropologiese model of antropologiese uitgangs-} punt moet die pastoraal gebruik maak?

Ek vereenvoudig die keuse maar tot twee moontlikhede: of die moderne (veral psigologiese) antropologieë ò die (wat ek wil noem) tradisionele sg. Christelike of teologiese mensbeskouing.

\subsection{Huidige (psigologiese) antropologieë}

In die lig van die geweldige taak wat die psigoterapie en pastoraal veral in ons tyd moet vervul, is dit tragies dat die meeste mensbeskouinge agter hierdie wetenskappe ò nie-Christelik of selfs uitgesproke anti-Bybels is.

Die groot gevaar van die meeste gangbare psigologiese mensbeelde is dat hulle met 'n eensydige, eendimensionele mensbeeld opereer. 
$\diamond$ Die psigo-analitiese skool reduseer die mens tot 'n biologiese drifwese. Volgens Freud is die gronddrif wat die mens beheers sy lusbevrediging en volgens Adler sy magsbevrediging (geldingsdrang). Hierdie sterk deur die evolusionisme beïnvloede denkwyses sien geen radikale verskil tussen mens en dier nie: die mens word deur sy „dierlike" drifte beheers.

Freud sien godsdiens/religie bv. as 'n illusionêre vervulling van infantiele behoeftes. God is bloot 'n projeksie van die skuldige mens, en godsdiens is dus 'n versperring op weg na werklike volwassenheid. Met sy godsdienstige illusies probeer die mens vir hom die lewe draagliker maak. Freud se visie van religie as 'n kollektiewe neurose (psigiese siekte) impliseer dus dat godsdiens iets abnormaals en gevaarlik is !

$\diamond$ Die behavioristiese skool het ook 'n eensydige mensbeeld, want

dit werk met 'n fisiologiese antropologie wat alle menslike gedrag tot fisiologiese en neurologiese faktore herlei. Byna soos in die geval van die psigo-analitiese skool word die hoëre dimensies van die menslike bestaan vanuit sy liggaamlike eksistensie verklaar. Die mens is 'n reflekswese wat op verskillende stimuli reageer en deur kondisionering soos 'n dier ,afgerig" kan word.

$\mathrm{U}$ besef die konsekwensies hiervan: indien die mens as 'n dier beskou word, moet hy ook soos 'n dier behandel word!

$\diamond$ Die fenomenologiese skool is gewortel in die eksistensialistiese denke wat ek seker nie met $u$ hoef te behandel nie.

$\diamond$ Ook Maslow se behoefteteorie is eensydig. Hy onderskei vyf basiese behoeftes by die mens, $\mathrm{nl}$. fisiologiese behoeftes, veiligheidsbehoeftes, die behoefte aan liefde (om iewers tuis te hoort), die behoefte aan prestasie en agting en die behoefte tot selfverwesenliking. Voorop in sy antropologie staan dus nie lusbevrediging (Freud) of magsbevrediging (Adler) nie maar behoeftebevrediging.

Dit is te begrype dat die teologie en die kerk baie wantrouig teenoor die moderne en kontemporêre psigologieë en psigoterapieë staan. Ongelukkig word egter dikwels die fout begaan, nl. dat die psigologie en psigoterapie as sodanig as uit die bose beskou word. Hiermee word 'n teologiese vak soos die pastoraal onnodig tot armoede veroordeel. Die sielkunde kan van groot hulp in die pastoraal wees.

Ek stem egter saam dat dit dan 'n werklik Bybels-begronde sielkunde moet wees. Te veel word daar nog van die gedagte uitgegaan dat ons nie van die grond af 'n reformatoriese antropologie en sielkunde hoef uit te bou nie: 'n blote verbetering aan die details ò die verwerping van die filosofiese grondslae van 'n onbybelse psigologie, en dit is geskik vir die Christen om te gebruik!

Miskien is dit die (dikwels vae) besef dat alles darem nie klop met bv. die psigo-analitiese skool dat vele teoloë maar liewer by hul tradisionele ,teologiese" antropologie hou.

\subsection{Tradisionele (teologiese) antropologie $\ddot{e}$}

Hieroor gaan ek nie veel sê nie. In „Onskriftuurlike trekke in die 


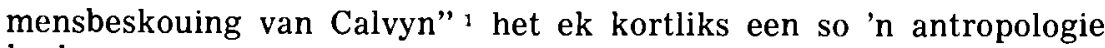
beskrywe.

Basies kom die meeste tradisionele "Christelike" antropologieë daarop neer dat die mens gesien word as 'n soort tussen-wese tussen die hoëre (geestelike) en die laere (stoflike) wêreld. In sy hoër deel (die siel/gees) is die mens aan die geestelike (dikwels goddelike) wêreld verwant en in sy laer deel (liggaam) is hy met die stoflike (aardse) verbonde. Aangesien die siel aan die transendente wêreld verwant is, kan die mens (in sy siel) ook die beeld van God vertoon. Die geestelike (ewige) bestaan van die mens is dan ook veel belangriker as sy aardse (tydelike).

Lees maar Herman Bavinck se Gereformeerde Dogmatiek en vele ander ouere teologiese werke en u sal hierdie model (met kleiner of groter variasies) terugvind.

In „Radical Biblical anthropology ..."2 het ek hierdie tipe mensbeskouing in die lig van die Skrif probeer ontmasker. Ek het ook aangetoon wat die gevolge daarvan in die praktyk is.

\section{Gevolge vir die pastoraal}

\section{Gespiritualiseerde pastoraat}

In 'n pastoraat op hierdie dualistiese antropologie gebou, sal die geestelike behoeftes van die mens ongetwyfeld voorrang geniet. Solank dit met 'n lidmaat se geloof (as deel van sy geestelike lewe gesien) in orde is, is alles reg. Die pastor of die diakonie kan dalk terloops ook na die "liggaamlike welstand" omsien, maar eintlik is dit nie sy taak nie. Daar word vergeet dat die geloof nie iets abstrak-geesteliks is nie: ' $n$ mens betuig jou geloof (of ongeloof) in jou konkrete woorde en dade. Ons sou hierdie tipe pastoraat as 'n geïnspireerde pastoraat kon bestempel wat die betekenis van die religie tot die ",boonste verdieping" van die menslike lewe beperk. Indien die mens - soos sommige doen - as etiese-(geestelike) religieuse wese gesien word, kan hierdie pastoraat ook in moralisme ontaard.

\section{Liggaamlike in die liturgie verwaarloos}

Laat my toe om met ' $n$ voorbeeld (meer van belang in die liturgie) te illustreer hoe ons nog steeds in die Griekse denkwêreld vasgevang is. Uit die weinige aandag wat ons aan ons liggaamshouding tydens die erediens gee, blyk duidelik dat die liggaam (as 'n mens so apart daarvan kan praat) nog nie werklik as ' $n$ inherente deel van ons Christenwees aanvaar is nie. Ons luister, spreke en sang sou dan wel in die ontmoeting met God betrokke wees, maar ons liggame is by hierdie sg. "geestelike dinge" uitgesluit. Dit terwyl in ons hele liggaamshouding, in ons ganse menswees, die aanbidding in die ontmoeting met die Here tot uitdrukking moet kom. God het ons ook liggaamlik geskape, sy verlossing geld ook ons liggaamlike bestaan. Ons hoef regtig nie skaam te wees dat ons 'n liggaam het (om maar die dualistiese taal te gebruik) nie! 


\section{Verwar geloof en psige}

Wat gebeur nou as hierdie tipe pastoraal met psigiese afwykings gekonfronteer word? Omdat die mens hiervolgens met 'n twee-dimensionele skema (liggaam-siel/gees) benader word, kan nie duidelik tussen die geloof (of ongeloof) en die psigiese (of psigiese afwykings) onderskei word nie. (Albei is maar ,geestelike” verskynsels). Psigiese steurnisse of emosionele probleme word as uitinge van ongeloof beskou. (Die kerk kan hom nie daarop beroem dat hierdie mense in die verlede altyd die nodige simpatieke behandeling ontvang het nie.) Omdat die psigiese of gevoelslewe van die mens met sy sielelewe (i.c. geloofslewe) verwar word (tradisioneel bestudeer sielkunde die siel), kan emosionele wanbalans alleen as sonde gesien word. Christene mag dus nie neurotiese probleme hê of selfs net bekommerd, bevrees of angstig wees nie. Christus het dan self gesê: „Moenie julle bekommer oor julle lewe...” Diegene wat aan spanning, frustrasie, angs en bekommernis ly, moet hulle dus bekeer en meer bid en glo.

\section{Dualistiese diagnose}

Psigiese siektetoestande word hier volgens verkeerde maatstawwe beoordeel, nl. religieuse of etiese. Ons doen dit tog nie in geval van ,somatiese" siektes nie. (Verkoue of kanker is tog nie sonde nie.) Hieragter sit egter die dualistiese gedagte dat die liggaam (as die veiganlilike deel) wel aan siekte onderhewig is en ook kan sterwe, maar dat die siel (as die onsterflike deel) nie. (,Geestelike siekte" is volgens hierdie standpunt 'n kontradiksie). Abnormaliteite in die geestelike bestaan van die mens moet dus volgens geestelike standaarde beoordeel word, selfs afgesien van die feit dat daar nie 'n direkte, kousale verband tussen siekte (ook psigiese siektes) en sonde of tussen geloof en gesondheid is. (Sien 'n mens nie dikwels die geloof die duidelikste by 'n dodelike sieke nie?)

\section{Waarmee dryf ons nou die duiwel uit?}

Met die moderne psigologiese antropologieë of die tradisionele teologiese antropologieë? Christus het al gewaarsku dat die duiwel nie met Beëlsebul uitgedryf kan word nie. Ons kan nie met 'n onbybelse antropologie die duiwel (soos openbaar in ongeloof, psigiese afwykings en al die gevolge van die sondeval) probeer uitdryf nie.

Werklike gereformeerde pastoraal vereis 'n werklik Skrifmatige antropologie. Dit kan ek nie aan u gee nie, want dit bestaan nog nie. Die buitelyne van 'n (l.w. nie dié) radikaal Bybelse antropologie bestaan egter in die artikel „Die mens: demonteerbaar, vernietigbaar of breekbaar?"3

\section{3. 'n Skrifmatige antropologie as vertrekpunt}

Die Skrif is natuurlik nie 'n wetenskaplike handboek nie (ook nie vir die antropologie nie). Dit is wel 'n voorwetenskaplike kenbron. Ook omtrent die mens bied dit sekere perspektiewe. Perspektiewe beteken nie 'n volledige mensbeskouing nie. Die gesigshoek waar- 
vanuit die Skrif die mens teken, is die religieuse.

Die term ,religie" dui op die sentrale, integrale en radikale verhouding tussen mens en God. Sentraal: religie hoort nie tot die periferie van die menslike lewe nie. Integraal: want dit gaan nie verlore in die veelheid van menslike lewensuitinge nie maar bind die hele menswees saam. Radikaal: want dit raak die wortel van die menslike bestaan van waaruit dit die hele mens as 't ware aan die brand steek.

Die mens se lewe moet nie net religie wees nie. Dit is religie. Om mens te wees, is om religieus te wees. Dit mag wees dat hy die ware God dien; dit mag wees dat hy 'n afgod dien - of dit nou deel van die skepping of ' $n$ verafgoding van die mens self is. Iets of iemand moet hy egter dien. Die hele lewe is religie. Of dit nou eksplisiet of implisiet ervaar word, bewus of onbewus teenwoordig is, dit is die grond van elke aktiwiteit of ervaring.

Religie definieer die mens, dit is die betekenis van sy bestaan. Vir die doel is hy geskape. In lewe en dood, wakker of aan die slaap, of hy werk en of hy rus, die mens staan steeds in 'n religieuse verhouding. Elke beroep is religieus en nie alleen die van die predikant nie. Religie karakteriseer ook elke organisasie en samelewing en nie alleen die kerk nie.

Buite die religie verval nie net alle betekenis van sy bestaan nie maar ook die mens self. 'n Nie-religieuse mens is 'n droommens - die droom van die mens wat probeer om vir die waarheid van sy bestaan te vlug.

Ons spreek dikwels van 'n irreligieuse mens wanneer iemand nie die ware God dien nie of wanneer hy nie doelbewus uitdrukking (in bv. kultus) aan sy godsdiens gee nie. Dit is egter nie korrek nie, want so 'n persoon verberg net sy identiteit: of hy weet nie hoe om sy diepste oortuiging tot uitdrukking te bring nie of hy is bang om dit te doen. Nogtans is hy 'n religieuse mens - want hy is 'n mens!

Omdat die religie die hele mens raak, gaan dit in die Skrif altyd om die hele mens in verhouding tot God en nie om die samestelling of struktuur van die mens (sy ,,dele") nie. Anders gestel: Die Skrif het geen belangstelling in die mens bloot as mens los van sy verhouding tot God nie. Uit die Skrif kan ons leer dat die mens 'n religieuse wese is of hy dit wil erken of nie, of sy hart positief of negatief tot God gerig is. (Dit teenoor sekere psigologiese antropologieë wat die religie as abnormaliteit beskou of nie tot sy reg laat kom nie, of die tradisionele teologiese antropologieë wat die religie inperk tot die sg. "geestelike" bestaan van die mens.)

Daarom is dit verkeerd om uit los versies oor bv. siel, liggaam, gees ens. konklusies te wil trek oor die komposisie van die mens. Wanneer die Bybel begrippe soos siel, gees, vlees, liggaam ens. gebruik, is dit nie dele van die mens waaroor dit gaan nie maar die (hele) mens vanuit verskillende kante of hoeke beskou.

As gevolg van die religieuse perspektief waarbinne die mens in die Skrif verskyn, word hierdie verskillende kante van waaruit die mens beskou word ook steeds in verband gebring met sy verhouding tot God. 
Die blyk duidelik as ons sekere ,, antropologiese begrippe" in die Skrif nader bekyk:

$\diamond$ Die mens as hart. Die begrip „hart” rig die aandag op die vaste punt of kernpunt waarin die mens volkome gerepresenteer word in sy essensie, nl. sy religieuse gerigtheid. Dit dui op die hele mens beskou vanuit die diepte van sy bestaan voor die aangesig van God.

$\diamond$ Die mens as gees. "Gees" is die gerigtheid van die mens. Dit dui op die hele mens gesien vanuit die rigtinggewende, motiverende krag van sy bestaan. 'n Mens sou kon sê die gees is die rigting van die hart, die mens beskou "van binne na buite". God se Gees rig en lei ook die menslike gees.

$\diamond$ Die mens as siel. Die woord "siel" slaan op die hele mens, die persoon, die ek as lewende wese. (Diere word in die Skrif ook "lewende siele" genoem!) As in gedagte gehou word dat God die Gewer van lewe is, blyk dit weer duidelik dat die mens ook in hierdie opsig met sy Skepper in verband gebring word.

$\diamond$ Die mens as liggaam. "Liggaam” is die gestalte van die mens. Dit teken die hele mens in sy konkrete verskyning as skepsel van God, d.w.s. radikaal verskillend van God.

Die mens as vlees. Hiermee word die hele mens gekarakteriseer as swak, breekbaar, nietig, stoflik - veral in teëstelling tot God wat ewig en onverganklik is. (Soms beteken dit ook sondige mens teenoor die geestelike mens, d.w.s. die mens wat deur Gods Gees beheers word.)

$\diamond$ Die mens as verstand. Ook dit dui op die hele mens in verhouding tot God maar hierdie keer gesien vanuit sy begryp en verstaan van God se openbaring.

$\diamond$ Die mens as beeld van God. Ook hiermee word die mens vanuit 'n sekere hoek van sy totale verhouding tot God geskets en wel in sy kindskap Gods en alles wat daaruit voorspruit. Moontlik kan ons hieroor tog iets meer sê. Eers kortliks iets oor hoe die ,beeld van God" deur die eeue verstaan is en dan ons eie interpretasie.

\section{Mens en die beeld van God}

Sommige het gedink, en baie dink vandag nog so, dat dié uitdrukking in die Bybel beteken dat die mens op een of ander wyse soos God Drie-enig lyk. Die voor-die-hand-liggende en letterlike betekenis van die woorde sou wees dat daar ten spyte van verskille 'n sekere ooreenkoms tussen Skepper en skepsel moet wees. Daar is tog ook ooreenkoms tussen 'n standbeeld of 'n foto van 'n persoon en die persoon self - al is die twee nie dieselfde nie.

Maar waarin moet die beeld of gelykenis van God in die mens dan gesoek word? Omdat vele Christene toe en tans geglo het en glo dat die mens uit siel en liggaam bestaan (wat soos twee onderdele van 'n masjien op een of ander wyse aanmekaar geskroef of gelas is) is die beeldskap van die mens in sy siel gesoek. In sy sogenaamde onsterflike siel is die mens aan God verwant want dit sou dan die hoëre, belangriker „deel" van die mens wees teenoor die 
laere, onbelangrike ou liggaam wat tog maar moet vergaan. Die siel was die goddelike in die mens en as die siel maar gered is, was alles in orde! By die ontstaan van elke mens skep God 'n siel in die liggaam (wat van beide ouers kom) en wanneer die mens sterwe, keer dié onsterflike, goddelike substansie weer na sy Oorsprong terug nadat die bande met die sondige liggaam verbreek is.

Gelukkig het andere (soos ook ons Belydenisskrifte) die beeld van God liewer gesien in sekere kwaliteite, soos kennis, geregtigheid en heiligheid, en nie in 'n wesenseenheid tussen God en mens nie.

Nog andere het 'n oplossing probeer bied deur op sekere karakteristieke aktiwiteite van die mens te wys. So byvoorbeeld sy kreatiwiteit (God is Skepper, die mens skepper), sy mag en heerskappy oor die skepping (God Heerser, die mens heerser), of die feit dat hy God se verteenwoordiger op aarde is (God is Koning, die mens onder-koning).

Sommige het egter ingesien dat op dié wyse alleen nog aan die omtrekke van die misterie geknaag word sonder om tot die essensie van die saak deur te dring: die genoemde kwaliteite of aktiwiteite van die mens is slegs die gevolge van die feit dat die mens God se beeld is en sê nog glad nie waarin die beeld self bestaan nie.

Teenoor diegene wat na iets goddeliks in die mens gesoek het om dit as beeld van God aan te dui, het daaropvolgende denkers beweer dat die beeld van God nie 'n wesenskenmerk van die mens is nie, maar dat dit gesoek moet word in die besondere verhouding waarin die mens tot God staan. Die mens is volgens hierdie standpunt dus ook nie outomaties en vanselfsprekend die beeld van God nie, maar vertoon alleen sy beeld wanneer hy in die korrekte relasie tot God staan.

Party geleerdes het weer diepsinnig daaroor gespekuleer of die feit dat, direk nadat in die Bybel van die mens opgeteken staan "na die beeld van God het Hy hom geskape”, volg „man en vrou het Hy hulle geskape", nie dalk 'n aanduiding is dat juis in die verhouding tussen man en vrou na die beeld van God gesoek moet word nie.

Wat kan die raaiselagtige uitdrukking ,geskape na die beeld en gelykenis van God" dan tog beteken?

Dit dui op afstand: God het die mens geskape (as iets totaal anders as Homself) na sy beeld. Soos wat Adam sy eie spieëlbeeld in die helder water van die paradysriviere kon gesien het, maar dit onmiddellik verdwyn het as hy klaar gedrink het, so is die mens vir sy menswees, sy beeld van God wees, totaal van God afhanklik.

Dit dui egter ook op nabyheid: God as Vader het die mens as sy kind geskape. Soos wat Eva in haar seuns en dogters iets van Adam en haarself kon bemerk, so wil God ook hê dat sy kinders op Hom sal lyk, dit is: sy verteenwoordiger of saakgelastigde sal wees. Let wel dat 'n verteenwoordiger van iemand nie letterlik soos sy sender hoef te lyk nie. In die ou Ooste het konings dikwels beelde van hulleself, wat glad nie soos hulleself gelyk het nie, in verowerde gebiede geplaas. Dit moes dien as teken dat, al kan hulle nie self daar teenwoordig wees nie, dit tog hulle magsgebied is. So moes Israel ook die beeldskap van God verstaan het. 
Die mens as die kind van God. Die hele mens - nie net die sogenaamde siel nie. Daarom kan ons ook nie sê die mens het God se beeld - asof jy 'n mens sou kry en dan nog iets ekstra daarby het wat van jou God se beeld maak nie! Die mens is God se beeld - egter ook nie vanselfsprekend en outomaties nie omdat daar geen wesenskontinuîteit tussen God en mens bestaan nie. Die mens is ook nie 'n beelddraer van God nie - hy kan nie, soos 'n wapendraer sy wapens, God se beeld opneem en neerlê nie! Gods beeld is ook nie in ons as iets aparts nie. Ons kan wel deeglik God se beeld verloor maar dan nie in die sin soos wat een of ander besitting verlore kan raak nie, maar in die sin dat ons, deur ongehoorsaamheid, sy beeld nie meer vertoon nie.

Die mens as beeld van God beteken dat die mens as gevolg van die inwerking van die Heilige Gees verteenwoordiger en magsdraer van God is, God se heerlikheid in sy goeie heerskappy oor die natuur weerspieël, in 'n kindskapsverhouding met God, in gehoorsaamheid aan God, heilig lewe.

Die hele mens in al sy dinamiek en aktiwiteit, die volledige mens in sy konkrete funksionering is nie net die beeld van God nie maar behoort dit voortdurend ook te wees. Ons het reeds gesê die mens bly nie sommer - soos 'n standbeeld of foto - vanselfsprekend God se beeld nie. Die gawe is ook 'n opgawe, die voorreg ook 'n plig.

Die verantwoordelikheid om God se beeld te wees, druis egter in teen al ons begeertes: ons wil nie God se beeld wees nie (imago Dei) maar soos God wees (sicut Deus). Ons het hopelik duidelik aangetoon dat die opvatting dat ,beeld van God" gelyk is aan „min of meer soos God" (in jou siel of wat ook al) juis die slinkse verleiding van Satan is en presies die teenoorgestelde van die waarheid. Satan het egter sy miljoene verslaan wat glo in die mens se outonomie, sy eie wetgewer, sy eie-baas-wees (wat dan vryheid sou beteken!), die waarheid aangaande die mens is en sy diepste geheim openbaar. Hierdie mens vertoon egter die beeld van iemand anders: die duiwel self !

Die mens as wil, gewete, persoon. Daar is nog meer sulke begrippe wat die mens in sy totaliteit tipeer waarop ons nie verder ingaan nie.

\section{Nuwe nadruk op ,eenheid van die mens”}

In die eerste plek dat die huidige klem van teoloë op die „eenheid" van die mens nie in die eerste plek die resultaat is van noukeuriger studie van die Bybel nie, maar a.g.v. die groeiende konsensus by wetenskaplikes uit allerlei ander vakrigtings hieroor.

In die tweede plek is met die nuwe beklemtoning van die ,eenheid" van die mens die volle waarheid nog nie bereik nie. „Eenheid” veronderstel nog steeds 'n eenheid van dele! (Waar die vroeër denke meer dualisties was - die mens is primêr 'n tweeheid wat saam 'n eenheid vorm - is die huidige denke meer monisties die mens is primêr 'n eenheid en sekondêr 'n veelheid). 
Dit is daarom, in die derde plek, dat die meeste denkers ten spyte van hul visie op die mens as eenheid nog steeds nie die sentraliteit van die mens raakgesien het nie, d.w.s. die konsentrasie van sy hele bestaan in die hart as religieuse sentrum.

\section{Enkele illustrasies van die betekenis van 'n Skrifmatige an- tropologie in die pastoraat}

Soos aan die begin gestel, is dit veral hier waar ons saam in die gesprek hierna die konsekwensies sal moet probeer deurtrek. Daarom slegs enkele punte:

\subsection{Die terrein van pastoraal}

Daar kan natuurlik baie definisies gegee word. Ek omskryf maar taamlik breed: Die pastoraal is die herderlike begeleiding van die sorgbehoewende mens.

Dit is duidelik dat hier 'n relasie tussen twee of meer mense veronderstel word en dat die pastor se opvatting van wie die mens is, daarom bepalend sal wees vir sy pastorale teoric en praktyk.

$\diamond$ Verder is dit voor die hand liggend dat die mens wat begelei word verskillende behoeftes kan hê waarna omgesien moet word.

Die psigoterapeut se doel sal veral wees om d.m.v. 'n bepaalde gesindheid (openheid vir die probleme, warmte en begrip teenoor die persoon) en met behulp van sekere tegnieke, helend in te werk op die psigiese funksionering van die pasiënt met die doel om die persoon te help om sy emosionele lewe wat "uit lit geraak het" weer in die geheel van sy bestaan te integreer.

Omdat die mens 'n eenheid is, sal die pastor ook met die psigiese of gevoelslewe van die lidmaat te doen kry. (Van daar die belang van 'n vak soos Pastorale Psigologie - 'n onderafdeling van die Sielkunde. Naas Pastorale Psigologie sou vakke soos Pastorale Ekonomie of Pastorale Etiek egter net so belangrik kon wees!) Ek dink dat die pastor se hooftaak egter op 'n ander terrein lê. Hy sal sy invloed rigtinggewend moet gebruik op die gebied van die godsdienstige (kerklik-kultiese) en (vandaaruit) religieuse bestaan van die sorgbehoewende mens. Ons omskrywing van wat pastoraal is, moet dus verder gepresiseer word: Pastoraal is die teologiese wetenskap wat as veld van ondersoek het die herderlike begeleiding van die (sorgbehoewende) mens op godsdienstig-religieuse gebied.

\subsection{Wat die fokuspunt van die pastoraal impliseer}

Alle hulp en leiding aan die (sorgbehoewende) mens is dus nie pastorale hulp of die taak van die pastor nie. (Net soos alle onderwys nie kategetiese onderwys is nie. Daar is verskillende tipes onderwys.) In noodgevalle waarvoor daar nie elders hulp te vinde is nie, kan die pastor dalk probeer help, maar hy moet versigtig wees om nie ,Jack of all trades" te probeer speel en op die ou end agter te kom dat hy "master of none" is nie. (Iemand van twaalf ambagte 
en dertien mislukkings.)

Ek plaas ,sorgbehocwende" in hakies om duidelik te maak dat die taak van die pastor nie net die „probleemgevalle" is nie. Eintlik gebruik ek ,pastoraal” hier dus baie breed in die sin van ,pastorale vakka". Ook die Kategetiek, Homelitiek, Liturgiek ens. is pastorale vakke, wetenskaplike besinning oor hoe die pastor sy werk moet verrig.

Die hulp wat die pastor aan sy medemens bied, is dus op 'n spesifieke terrein, nl. die godsdienstig-religieuse. $U$ weet wel dat onder "godsdiens" die engere (sê maar kerklike, meer ,direkte”) en onder ,,religie" die breëre (sê maar wêreldlike, meer „indirekte”) diens aan God verstaan word.

\section{Psigoterapeut, psigoloog, medikus}

Die psigoterapeut help die mens om sy psigiese lewe weer normaal in diens van God te kan gebruik. Die medikus genees die mens sodat hy liggaamlik in staat is om God te verheerlik. Ook die onderwyser voed die kind op om God te kan dien. Hierdie mense is dus - as hulle hul taak reg verstaan - met religieuse begeleiding besig. Die pastor is dus nie die enigste wat religieuse leiding verskaf nie. Hy verskaf sy hulp op 'n spesifieke gebied, nl. die geloofs-kerklik-godsdienstige lewe. Omdat die geloof en die religie egter nooit van mekaar geskei kan word nie (alhoewel dit onderskeibaar is) het ons die veld van die pastor (teenoor die psigies-religieuse van die psigoterapeut, die opvoedkundig-religieuse van die onderwyser ens.) as die godsdienstig-religieuse aangedui.

In die praktyk kom dit ongelukkig meestal daarop neer dat die psigoloog, die medikus en selfs die opvoedkundige hulle weinig steur aan die religieuse diepte-dimensie van die mens waarmee hulle (elk op hul eie gebied) te make het. Die pastor moet die las dan ook nog op hom neem. Vandaar dat ons verderaan (al is dit bietjie onnoukeurig) kortheidshalwe sommer van die pastor se religieuse taak spreek.

\section{Religie}

Religie - in watter rigting ook al gerig - is 'n dinamiese energie. 'n Gesonde religie (tot die ware God gerigte lewe) lei tot oorgawe, geborgenheid, aanvaarding, toewyding, sinvolheid van die lewe, selfverloëning en liefde. Die ware religie het 'n integratiewe waarde, dit hou die mens ,heel". Die afvallige religie (omdat dit op 'n afgod gerig is wat nie werklik kan bevredig nie mar die mens moet teleurstel) kan nie anders as om uiteindelik (psigologies gestel) tot disintegrasie en selfs neurose te lei nie. (Van die ander kant gesien kan ,ongeloof", d.w.s. verkeerd gerigte geloof - geen mens is sonder geloof nie - natuurlik ook die gevolg wees van psigiese afwykings van neurotiese aard).

\section{Fundamentele pastorale begeleiding}

Die pastor is dus met fundamentele, grondliggende, rigtinggewende leiding besig. (Ongelukkig besef alle pastors dit nog nie. Vele is 
heeltemal tevrede as hulle lidmate getrou kerk toe kom en voldoende kerklike bydraes gee. Alle aandag word dus alleen op die kerk gesentreer, terwyl die pastorale begeleiding veel dieper en ook veel breër behoort te wees.)

Ter illustrasie slegs enkele fasette van hierdie begeleiding:

$\diamond$ Begeleiding tot konsekwente radikaliteit. Die lidmaat moet besef dat sy ganse lewe religie, diens is aan of God of Satan.

$\diamond$ Begeleiding tot konkrete ekspressie van sy religieuse oortuigings nie net in Bybellees, gebed en erediens nie, maar ook in sy lewensstyl van elke dag op alle terreine.

$\diamond$ Begeleiding tot daadwerklike strydvaardigheid teen die sonde en gebrokenheid van ons bestaan en positiewe uitbou van die goeie wat die lewe tog nog bied.

$\diamond \quad$ Begeleiding tot ' $n$ insig in die eie unieke opdrag en 'n dankbare uitlewing daarvan.

Die gevaar lê in die invloed van allerlei eensydige humanistiese persoonlikheidsideale in ' $n$ pastoraat. Vele pastors in die verlede het geswig voor die verleiding om as einddoel van hul bemoeienis met die medemens o.a. te sien:

$\diamond$ die goedopgevoede mondige man of vrou;

$\diamond$ die bekwame, beskaafde persoonlikheid;

$\diamond$ die goedgeïntegreerde of welaangepaste mens;

$\diamond$ die eties-betroubare medemens;

$\diamond$ die verantwoordelike burger of selfs

$\diamond$ die bekeerde, vrome Christen.

Wanneer een of meer van hierdie fasette van menswees as dié doel van die pastoraat gesien word, word dié betekenis van die menslike lewe, (nl. die religieuse) vervlak, vervals en verdraai. Dan word pastorale sorg ' $n$ instrument vir die selfverheerliking (i.p.v. Godsverheerliking) van die mens wat uiteindelik tot sy selfvernietiging lei.

Die mens het net één roeping (al is dit ryk gedifferensieerd) en dit is om God lief te hê (en dus te dien) met sy hele hart en sy naaste soos homself. Op hierdie sentrale roeping moet die pastoraat toegespits wees.

\section{3. 'n Geweldige verantwoordelikheid}

Enige mens wat met mense werk en vormende invloed op hul lewe uitoefen, dra groot verantwoordelikheid. In die uitvoering van sy taak mag hy nie maar sy eie wense, drange en begeertes volg nie en nog minder enige metode gebruik wat hy nodig vind om sy doel te bereik. Die mag oor ander mag nie maar na willekeur uitgeoefen word nie.

Die pastor het in hierdie opsig 'n dubbelswaar verantwoordelikheid. Om pastoraal besig te wees is om daadwerklik rigting te gee aan die ontwikkeling van die diepste en beslissendste grondlaag van ' $n$ mens se lewe, om hom na die laaste en hoogste doel van sy bestaan te lei. 
Hierdie begeleiding moet egter steeds volgens bepaalde norme geskied. Een van die norme is dat die mens self gerespekteer moet word. (Hier sien u weer eens die belang van die Christelike antropologie!) Pastoraal moet o.a. nie menslike vryheid en verantwoordelikheid afbreek i.p.v. dit te help ontwikkel nie.

Pastorale sorg kan aan die een kant ontaard in 'n demonstrasie van geestelike oorheersing, dwang, manipulasie of selfs meganiese kondisionering. Die ander uiterste is dat die pastor 'n laat-maar-loophouding inneem.

Eersgenoemde vorm van optrede kan lei òf tot vreesbevange onderwerping, onvolwassenheid (in die geloof), neurotiese tendense en selfs permanente skade, of tot hardkoppige rebellie en aggressie. Die tweede houding kan verwarring, onsekerheid en twyfel tot gevolg hê.

Anti-normatiewe houdings (wat die resultaat is van verkeerde mensbeskouings) lei onvermydelik tot pastorale impotensie en mis. lukkings.

Vollenhoven, Dooyeweerd en Stoker se modaliteiteleer is van waarde. Die leer van die wetskringe gee aan ons vrugbare perspektiewe t.o.v. die mens, hoe $u$ verhouding as mens tot $u$ medemens in $\mathrm{u}$ pastorale aktiwiteit behoort te wees. Fasette wat van belang is, is die volgende:

Gee individuele aandag (getalsaspek).

$\diamond$ Kies die geskikte plek en die regte tyd vir u gesprekke (ruimtelilie-lydelike faset).

$\diamond$ Behou balans tussen nabyheid en afstand. Daar is dinge wat $u$ moet weet om te kan help, maar ook dinge wat $u$ nie hoef te weet nie (fisiese faset).

$\diamond$ Hou rekening met die ontwikkeling, leeftydsfase ens. van die persoon wat $\mathrm{u}$ wil help (biotiese faset).

$\diamond$ Gaan sensitief, versigtig om met die gevoelens en oortuigings van $\mathrm{u}$ medemens (psigiese aspek).

$\diamond$ Onderskei skerp en dink logies om die verwarring by die broeder of suster nie nog groter te maak nie (analitiese faset).

$\diamond$ U mag nooit van u mag of gesag oor andere misbruik maak nie. Dit moet nie tot $\mathrm{u}$ voordeel maar juis tot hulle voordeel gebruik word. Vergelyk wat hierbo reeds in die verband gestel is (die vormatiewe aspek).

$\diamond$ Spreek in helder, duidelike eenvoudige taal (linguale faset).

$\diamond$ Laat daar warmte en openheid by $u$ wees teenoor $u$ medemens (sosiale faset).

$\diamond$ Stel $\mathrm{u}$ te enige tyd vryelik beskikbaar sonder om die indruk te skep dat $u$ haastig is (ander belangriker werk het of $u$ tyd gemors word, ekonomiese faset).

$\diamond$ Onthou u kan veel op indirekte wyse met bv. suggestie bereik (estetiese faset).

$\diamond \quad \mathrm{U}$ het die verantwoordelikheid om lidmate te beskerm o.a. deur geheimhouding van wat vertroulik aan $\mathrm{u}$ meegedeel is (juridiese faset).

$\diamond$ In absolute opregtheid, eerlikheid en trou moet $u$ u gee vir die heil van u naaste (etiese faset). 
$\diamond$ Laaste, maar nie die minste nie: 'n heldere bewustheid van die einddoel van die pastoraat, $\mathrm{nl}$. fundamentele, religieuse dieptebegeleiding "sodat die mens van God volkome kan wees, vir elke goeie werk volkome toegerus" -2 Tim. $3: 17$ (die geloofsfaset).

(Praatjie gelewer voor die Teologiese Studentevereniging (Potchefstroom) op 24 Junie 1977.

1 Sal gepubliseer word in Tydskrif vir Christelike Wetenskap (1977).

2 Gepubliseer in Koers, XL (4/5/6): 380-401, 1975.

3 Gepubliseer in Perspektief, 6 (1): 25-50, 1968.

LITERATUUR:

De Graaf, A. H.: A Christian perspective in Psychotherapy: Same Theses. In: Anthropology and psychology in Christian Perspective. Toronto, ICS, 1975, p. $90-98$.

De Klerk, W. J.: Pastorale sensitiwiteit. Johannesburg, Perskor, 1975.

Kotze, G. J.: Die Antropologiese onderbou van die Geref. Pastoraat. Proefskrif $\mathrm{PU}-1971$.

Van den Berg, J. H.: Psychologie en theologische antropologie. Nijkerk, Callenbach, 1952. 